ljtihad, Jurnal Wacana Hukum Islam dan Kemanusiaan

Vol. 18, No. 1 (2018), pp. 57-80, doi : 10.18326/ijtihad.v18i1.57-80

\title{
Care ethics of women as institutionalization of equality and peace building at grassroots level in West Java
}

\author{
Sumadi \\ Graduate Program of Institut Agama Islam Darussalam Ciamis \\ Jl. Kiai Abmad Fadil No.1 Dewsari Ciamis West Java \\ E-mail:Sumadi2009@gmail.com \\ DOI: 10.18326/ijtihad.v18i1.57-80
}

\begin{abstract}
Tulisan ini mendasarkan pada latar belakang bahwa suasana damai adalah sebuah keniscayaan harus dipelihara sepanjang waktu. Jawa Barat sebagai provinsi dalam berbagai survei ditempatkan sebagai daerah dengan kasus dan peristiwa intoleransi yang tertinggi dibanding daerah lain di Indonesia. Tetapi di sisi lain berbagai gerakan bina damai sesungguhnya telah banyak dilakukan oleh masyarakat Jawa Barat bukan saja di pusat, bahkan di grassroot level. Para perempuan dengan modal care ethics (etika kepedulian) telah melakukan bina damai yang mampu memberi kontribusi perekat sosial yang kuat di daerah. Care ethics perempuan dalam berbagai aktifitasnya secara sekaligus menjadi ruang pelembagaan kesetaraan dan bina damai.
\end{abstract}

This paper is based on the background that peace is a necessity which should always be maintained. Surveys often show West Java as a province with the highest cases and events of discrimination compared with other regions in Indonesia. However, people of West Java have established many peace building movements at central and grassroots levels. Interestingly, peace building movements are often started by women. Peace building can be an area of gender equality. This study was a qualitative study with in-depth interview and observation. The research result showed that women with care ethics who joined peace building were able to contribute as strong social glue in the field. The care ethics of women in their activities also institutionalized equality.

Keywords: woman; care ethic; equality; peace

\section{Introduction}

In a society free from conflict and war, maintaining peaceful and harmonious life is a necessity 
ljtihad: Jurnal Wacana Hukum Islam dan Kemanusiaan, Volume 18, No. 1, Juni 2018: 57-80

for everyone. In this context, women have significant roles. The capacity, integrity, and psyche of women are started to be viewed as important to be agents of peaceful life. Spirit and confidence on women are written in Women Peace Conference II (2017) in Jakarta to be the vision for women to stand, protect, and build civilization wisely, thus creating peaceful world civilization. The inspiration is an important step to reaffirm women as agents of peace.

During the New Order era, women were gathered and controlled by the state in Dharma Wanita or Family Welfare Movement (PKK) from the central government to grassroots levels, which still exist today. The women who were active in public, e.g. Gerwani (Wieringa, 1992), in the New Order era were stereotyped as promiscuous and amoral women. Therefore, Indonesian women who were actually capable didn't appear in public space during the New Order era as communities who were active in their roles (speaker) and didn't receive access to the role as keepers of peaceful and harmonious life. The impacts of sexual politics in culture and politics still exist today in Indonesia.

In academic context (Sumadi, 2017), there are problems of dominating perspective and epistemology which oppress and marginalize women. Historical influence is institutionalized in the officials, e.g. in education, religion, politics, and culture, which deem women to not have capacity in large public space, e.g. as peacekeeper. However, empirically, Indonesian women have an important part as public leaders in creating peaceful and harmonious life.

After the reform, there were many political conflicts triggered by religion, tribe, and race. The threat of conflict still exists. According to the survey of Wahid Foundation (2016), the majority of Indonesian Muslims refuse radicalism (72\%). However, $7.7 \%$ are ready to participate in radicalism and $0.4 \%$ has been involved in activities on the behalf of their religion. $0.4 \%$ of 150 million Muslims means 600 thousand people have been involved and $7.7 \%$ means around 7.7 million people potentially commit violent acts (metronews.com, accessed on 4/10/17). Although the numbers are only projection rather than factual, it's still worrying. All elements of the society should perform peace building more actively.

Specifically, West Java is the province with the highest number of cases of radicalism and intolerance in the name of religion in Indonesia. According to the National Commission on Human Rights, in 2016 there were 97 complaints on freedom of religion and faith. West Java had the highest number of complaints with 21 complaints which increased form the 
previous year by 20 complaints (pikiran-rakyat.com, accessed on 5/10/17). Other surveys also show that West Java has the highest number of cases of intolerance. In 2016, Setara Institute recorded 208 violations of freedom of religion and faith with 270 action types in Indonesia. Most violations happened in West Java with 41 violations, followed by DKI Jakarta (31 cases) and East Java (22 cases). In early 2017, the National Commission on Human Rights ranked West Java number one in terms of the number of cases of intolerance of rights for freedom of religion and faith in Indonesia. LBH Bandung noted that from 2005 to 2011, there were 383 cases of violence and violation of freedom of faith in West Java. In fact, the survey by Wahid Foundation shows that 80 percent of suicide bombers in Indonesia were from West Java (beritasatu.com, accessed on 5/10/17). According to Setara Institut, since 2004 to 2016, West Java had the top rank of intolerant provinces in Indonesia.

The index of harmony of West Java is also below national average. A survey of the Agency for Research and Development and Training of the Ministry of Religious Affairs (balitbangdiklat.kemenag.go.id, accessed on 5/10/17) measured three main indicators to gain the levels of the society's Religious Harmony (KUB), i.e.: 1) Tolerance, 2) Equality, and 3) Cooperation. By measuring the indicators, the survey shows that fourteen provincial cities have KUB level above the national average of $75.36 \%$. They are: 1) East Nusa Tenggara (83.3\%), 2) Bali (81.6\%), 3) Maluku (81,3\%), 4) Central Kalimantan (80.7\%), 5) North Sulawesi (80.5\%), 6) Papua (80.2\%), 7) Central Sulawesi (78.8\%), 8) Southeast Sulawesi (78\%), 9) West Papua (77.7\%), 10) Central Java (77.6\%), 11) South Kalimantan (77.4\%), 12) North Sumatera (77.1\%), 13) North Maluku (76.8\%), and 14) West Nusa Tenggara (75.7\%).

Peaceful and harmonious life is determined by the roles of women and men. According to the Ministry of Women's Empowerment and Child Protection, (gender development index, GDI) of West Java in 2016 (kemenpppa.go.id, 5/10/17) was 55.77 point. It shows that West Java is below national IDG score of 62.3. It means there is worrying inequality toward women. The province closest to the state capital shouldn't have suboptimal women's empowerment.

Based on the description above, West Java faces two fundamental problems, i.e. religious tolerance and gender gap. Gender relation is closely related with peaceful life. Women could be subjects in creating peaceful and harmonious life in a community. However, the opposite 
ljtihad: Jurnal Wacana Hukum Islam dan Kemanusiaan, Volume 18, No. 1, Juni 2018: 57-80

could be true and women are exposed to various conflicts due to the burdens they're carrying. In many conflicts, women become victims and carry heavy loads. When men join conflicts and become casualties or permanently disabled, women fulfill household needs. They survive to provide for themselves and their children, become head of the household, and even become agents of peace for their communities.

With their potentials, like women in Aceh (Oktaviana, Santoso, Purwoko, 2014), women are better in surviving conflicts and post-conflicts. It's because the perspective of women prioritizes togetherness over conflict. In this context, according to Gilligen (in Maharani, 2013) women use care ethics rather than reinforcement of rights to justice. The fundamental potentials of women with care mentality enable social intimacy to build peaceful and harmonious life.

Therefore, it's important to advocate gender gap and religious harmony crisis in West Java. In the context of gender, making women agents of peace building is an effort to improve gender equality and eliminate cases of intolerance. This article aimed to discuss the activities of Muslim women who were active in grassroots to build peace in a province with the highest number of cases of intolerance in Indonesia. It's a narrative of women who build peace to answer uncertain harmony in West Java. The stigma of intolerant Muslims will be disproven by peace building practices performed by Muslim women. This study is also the first step to growing social awareness and recognition of the role of women which is equal to that of men, as well as creating peaceful life which is usually viewed as men's field.

The present study used qualitative approach with phenomenological paradigm, descriptive method, and based on women's perspective. The data collection techniques were in-depth interview and document analysis of texts and pictures. It will describe a number of women in their equal roles in maintaining peace. They are: First, Mrs. Hj. Eulis Fadlilah Jauhar Nafisah, the caretaker and leader of Darussalam pesantren, Ciamis. She managed the pesantren based on the principle of care which opposes various ideologies and violence with the vision that "moderate Muslim, democratic believer, and diplomatic mubsin". Second, Mrs. Dasiah. She’s a village head amidst a controversy of rejection and doubt of female leadership. Mrs. Dasiah is the Head of Sindang Angin Village, Lakbok Sub-District, Ciamis Regency. Sindang Angin is a village located in the far east of West Java, bordered by Central Java. The village has 
dynamic social, cultural, and political conditions. Third, Hj. Herman, a businesswoman amidst Confucianism, Catholic, and Christian communities. She established Al-Mujahidin mosque with her own money. It's a mosque managed by Hj. Herman amidst Christian, Catholic, and Confucianism communities with caring and harmonious approaches.

This study is theoretically based on Galtung (Panggabean, 2017) who explains that peace maintenance isn't tied to post-war situation and atmosphere. Peace maintenance isn't a phase or temporal stage, but a dynamic process involving many activities in normal and post-war conditions, and/or after the end of violence. Moreover, maintaining peaceful life isn't limited to national or international levels, but also sub-national level, especially cities an regencies which are parts of regions covered at grassroots level.

\section{Women and peace}

In civilizations, women have different gender roles based on their cultures, classes, religions, races, and government systems in their countries. Gender discrimination has existed since the beginning of history. The discriminations harm women more than men. Men are set to be leaders of women with some attributes from the start, e.g. men are leaders, strong, well-built, intellectual, and broad-minded. Conversely, women are considered to be less intellectual than men, weak, sexual objects, men's servants, child caretakers, and belonging at home or behind men. Simone de Behavoir (Gamble, 2010:296) states that one isn't born "woman" but becomes "a woman". Becoming a woman is social formation and cultural expectation in a community. Imbalance relationship ethics between men and women harm women. Unfortunately, the gender-biased socialization still happens today (Sumadi, 2016). There is a view that women aren't suitable to be leaders or to occupy public offices. The physique and sexuality of women are still viewed as obstacles for women to occupy social, political, and religious roles equal to men. Academic context (Sumadi, 2017) is still dominated by patriarchal perspective and epistemology with hegemony of gender-biased ideologies, thus naturally oppressing women.

According to Tobach (2008), in prehistoric time, male or men were strong figures. Women were conceptualized and constructed to have caretaking role to produce offspring. Meanwhile, men performed various reproductive activities for their female partners and children. The 
ljtihad: Jurnal Wacana Hukum Islam dan Kemanusiaan, Volume 18, No. 1, Juni 2018: 57-80

idea that female is the gender of agent of peace comes from the concept that women are natural caretakers and men soldiers. Here, battles and wars were from men, while women were calming in nurturing and caring.

In another aspect, female gender as agent of peace refers to Gioseffi and DePauw (Tobach, 2008) who state that in terms of class and power, women who own inherited land or wealth or women who inherit political power, e.g. being queen, tend to be militaristic as war and political leaders like men. It means that culturally dynamic and different social situation make women in some parts of the world have capacity and roles which are determined by their communities to be the roles and activities of men.

Haynie (2011) studies the relation between women and peace on (the percent of women in the parliaments and executive cabinets of 93 nations over a 31-year-period, comparing these figures to the presence of violent interstate conflicts for each country-year) by comparing women's roles and final trends in 93 countries involved in conflicts for 31 years. The control variables of this study was GDP per capita, military spending, national capability, year since women receive civic and political rights, presidential or parliamentary model, and democratic status. Haynie (2011) in Can Female Leaders Bring About World Peace, hypothesizes: the higher the percentage of women elected or appointed to a nation's parliament and executive cabinet, the lower that nation's likelihood of violent interstate conflict? It shows that the higher the election and establishment of national government, whether in executive or legislative, contributes, the smaller the chance of conflict between countries.

In 1928, a British woman named Margaret Smith (Schimmel, 1996), wrote about Rabi'ah, the first zabidin Islam (w.801 in Iraq). Rabia'h is considered to be the woman who introduces the element of pure love during early ascetic movement in the Islamic world which is praised by future writers and poets. Schimmel (1996) also states that in the Middle Ages, there were several queens, e.g. Radhiyah Sultanah (1236-40) from Delhi and Syajarat Al-Dur from Egypt (1246-49). Many other queens were able to influence their husbands in their political decisions and policies. Many royal women were praised by poets for their role in creating love and harmony in the society.

Women in the society in the hypothesis and cultural data above affect peace. Therefore, improved education and equality in a country encourages women to create peace. Although 
in some cases, women's concern seems less than men's, the gap is a part of the dynamic process to create gender equality in world peace.

Therefore, in feminism, women's roles in war and peace building are efforts to create gender equality between men and women. "Men"-based approach based on rights and justice is one-sided in developing culture with appreciates diversity in the framework of equality. Women who become peace workers with care ethics socialize gender equality between women and men. Women and children will get an idea of equal roles between men and women.

Marginalization of women in male-dominated conflict resolution and peace leads to domination of men's interests and politics. The roles will reinforce the stereotype that women are weak and incapable of leadership. Gilligen (Widiarti, 2003; Maharani, 2013) states that the significance of care ethics shown by women will socialize and inspire people, female victims of conflicts, and children to have equal empowerment.

Today, global social recognition, including formally by the UN through the resolution of Un Security Council No 1325 establishes women as peace and security keepers. The UN (Hutabarat, 2017) explicitly recognizes women in creating peace and security in world community during conflict and after conflict. Including women in international peace agenda is an important part of awareness of the significance of gender perspective in building peaceful life and resolving various conflicts. Gender perspective in creating peace is putting female peacekeepers as role models to inspire women, girls, and children to make them realize their rights as the main pillars of peace which have been dominated by women.

Today, peacekeeping is performed by many educational agencies, NGOs and individuals at national and regional levels, e.g. CRCS Universitas Gadjah Mada, Religious and Democracy Study center of Paramadina Waqf Foundation, The Wahid Institute, Setara Institute, NU, Muhammadiyah, etc.. They perform socialization, scientific studies, academic writing, and other advocacies of peace in Indonesia.

When playing multiple roles (Carolina, 2013), mothers remain partial by protecting nature from destruction which is a $21^{\text {st }}$ century issue. In their own ways, mothers fight oppression, including natural oppressions by environmental destroyers who are basing themselves on political and economic interests.

The role of women as agents of peace in Indonesia have been implemented in various 
ljtihad: Jurnal Wacana Hukum Islam dan Kemanusiaan, Volume 18, No. 1, Juni 2018: 57-80

conflict areas such as Aceh (Wulandari, 2009). Female activists of Aceh (Rosmiati, 2016) create peace using empowerment and advocacy, e.g.: first, they defend themselves, their families, and communities; second, they perform capacity building and reinforcing among women using mentoring program; third, they play roles which contribute to development. Aceh women who lost their properties and husbands rose to join peace building and peace keepers.

During conflict, such as in Aceh (Oktaviana, Santoso, Purwoko, 2014), women are marginalized. Despite being victims, women are also important actors of peace. However, women are often not formally included. During peace building, women have significant roles, however due to sexual politics, they are marginalized because conflict resolution often ignore the rights of victims, i.e. women. Aceh women face many minor and major conflicts, e.g. agrarian conflicts (Oktaviana, Santoso, Purwoko, 2014). The informal efforts of Aceh women to create peace have significant and decisive contributions.

In West Java, which is known for high level of intolerance in Indonesia, there are a number of people building peaceful and harmonious society. The study by Panggabean and Ali Fauzi (2017) from the Religious Study center of Paramadina, describes the experiences of 6 people in West Java whose principle of life, activities and professional duties are devoted to creating peaceful society. Three out of the six people are women.

\section{Women at grassroots level to institutionalize equality and peace}

Maintenance of peaceful and harmonious life in Indonesia can be viewed from two sides, i.e.: first, peacekeeping with well-planned work program individually or institutionally; second, non-institutional peacekeeping without controlled program, but with action, principle of life, and policy which strongly affect maintenance of peaceful and harmonious life (Panggabean, 2017:1). Two roles of peacekeepers and harmonious life are important and significant in creating awareness and social order which respect diversity. The creation and maintenance of harmonious life are comprehensive activities in a dynamic society. It requires various entities which reinforce each other.

Therefore, the roles of peacekeepers at grassroots level should be reinforced.

Hj. Eulis Jauhar Nafisah: managing pesantren with care and epicenter of moderation: 
Care ethics of women as institutionalization of equality and peace building at grassroots level...(Sumadi)

\section{"Moderate Muslim, Democratic Believer, and Diplomatic Mubsin".}

Dra.Hj. Eulis Jauhar Nafisah, M.Pd.I in Ciamis Regency is known as Hajah Eulis. Her late father, KH. Irfan Hielmy calls her Neneng. $\mathrm{Hj}$ Eulis is known as Kartini of pesantren. There are three reasons why she's called Kartini of pesantren. First, she cares for and is active in women empowerment in Ciamis; second, $\mathrm{Hj}$.Eulis is a successful female leader in school, pesantren, and community; Third, Hj. Eulis was born on 21 April 1957 which is the birthdate of R.A Kartini.

Since she was a child, her father, KH. Irfan Hielmy, taught her leadership. Her father is a famous and influential Kiai in West Java, leader of pesantren, author, and expert preacher. When she was young, she often travelled with him to preach. Before her father started preaching, young Hj.Eulis was told to start with lecture and spiritual discussion for the public. This was unusual because decades ago, children, especially girls, didn't advice the public. However, KH. Irfan Hielmy taught $\mathrm{Hj}$. Eulis strong leadership since she was young by training, socializing, and building relations as social bonds. Her experience in preaching, visiting, and understanding diversity in the society in various regions impacts Hj. Eulis's leadership.

Therefore, Eulis had hold many leadership positions with her capacities, e.g. teacher, principal, leader of pesantren (Pesantren Care Board), and other public social offices. In 2010, Eulis' father passed away. Since then, $\mathrm{Hj}$. Eulis and her brothers and sisters led Darussalam pesantren, Ciamis which had thousands of students and tens of thousands of alumni across Indonesian and the globe. She led and built the pesantren with the principle of Moderation with the culture of "Moderate Muslim, Democratic Believer", and Diplomatic Mubsin. With this, Hj.Eulis managed and built pesantren as an epicenter of peace.

The concept of education development as a process of peace building to create moderate Islam was found by Hj.Eulis based on her father's ideas (Nafisah, 2017) that education has three objectives, i.e. individual, social, and national objectives. The three elements of peace buildingbased education aim to prepare and create complete human (insan kamil). In terms of social aspect, education as a process of peace building is directed to create the best people (khairu ummah). Nationally, peace building education is directed to build civil society and moral country.

For $\mathrm{Hj}$. Eulis, three objectives and educational activities in teaching her students 
ljtihad: Jurnal Wacana Hukum Islam dan Kemanusiaan, Volume 18, No. 1, Juni 2018: 57-80

emphasized on care ethics. Individuals were taught to create complete personality to create peace. The characteristic of complete individual was called insan kamil, i.e. individual with peaceful personality, ingrained faith and piety, nobleness, intelligence, skill, creativity, independence, and physical and mental health.

Socially, the individuals were directed to be agents of Khairu Ummah, which is people who have social role and concern by spreading goodness and truth (Al-Ma'ruf), preventing badness and crime (al-munkar), being faithful to Allah SWT.

In the context of diverse country, the education in Darussalam pesantren according to $\mathrm{Hj}$. Eulis created civil society, a society built with diversity which respects differences in various aspects of life. Civil society was created by, first, following the example of Medina society built by Rasulullah SAW upon Madinah agreement (Shabifah Madinab); second, creating civilized and noble society; third, respecting diversity and tolerance, third, supremacy and law enforcement; fourth, realization of social justice; fifth, high citizen participation.

Internally in Darussalam pesantren Ciamis, $\mathrm{Hj}$. Eulis united diversity. For $\mathrm{Hj}$.Eulis, the pesantren must be harmonious first of all, specifically through Board of Women's Silaturabim (MSI) in Darussalam pesantren joined by teachers of pesantren, kindergarten, Madrasah Ibtidaiyah (MI), Madrasah Tsnawiyah (MTs), Madrasah Aliyah Darussalam, SMA Plus Darussalam, and IAID Ciamis. MSI was a place for silaturabim and unity of female educators in Darussalam pesantren. Through MSI, the women were taught and trained to respect, care, and be skillful to empower them. Therefore, since $2001 \mathrm{Hj}$. Eulis regularly led the organization with various programmed activities.

Through MSI, women were given opportunities to express themselves as empowered women, e.g. master of ceremony, lecturer, prayer reader, and innovator. Specifically, women's innovations were unique features of MSI events. The women can display their works, e.g. food, clothes, souvenirs, and other productive skills.

As the pesantren leader, $\mathrm{Hj}$. Eulis showed her social care by devoting herself to various community organizations. She led Indonesian Women's Silaturahim Coordinating Board (BKSWI) of Ciamis Regency. It's a women's organization which previously was used for political interests. Hj. Eulis changed it to accept all women's organization regardless of ideology and vision. With principles of care and moderation, Hj.Eulis made BKSWI unifier 
of various women's organizations, including: Persistri (PERSIS Women Association), Aisiyah (Muhammadiyah Women), Muslimat (NU), Alhidayah (Golkar Muslim Women), and Women of Islamic Company. It included Salimah which is a women's organization of PKS which previously wasn't included. Different ideologies and visions of women's organizations were united by Hj.Eulis in the framework of silaturahim. Hj.Eulis didn't dominate women's organizations in BKSWI. Everyone had the same role in building harmony among community organizations and people of Ciamis Regency.

With the principle of moderation passed by her father, the aspirations and ideological principles of all women's organizations were given space for expression in various organizational activities. It included holding public recitations by involving community organizations in Ciamis Regency with speakers from various community organizations in turn. Maternal instinct to raise and care gave everyone to express their religious aspirations and visions. Although Hj.Eulis admitted that not all ideas and views of the women's organizations matched her principle, respecting difference was more important than emphasizing it.

Mosque Taklim Assembly Coordinating Board (BKMM), an Islamic organization in Ciamis Regency, wasn't led by her, but the managers often asked for her advices and assistance. Therefore, $\mathrm{Hj}$. Eulis became speakers in recitation events. $\mathrm{Hj}$.Eulis even spared her time for arts in BKMM. One of the arts she gave financial aid, time, attention, and mentoring was choice. Hj.Eulis herself led BKMM choir practice because they didn't have enough budget and human resources to train them. $\mathrm{Hj}$. Eulis designed choir practice program to channel the interests and talent of women in Ciamis Regency. As a result, BKMM Choir performed in many social events in Ciamis Regency. In 2017, the choir won West Java BKMM Choir Competition. Volunteerism and total care made the choir the pride of BKMM and women Ciamis although BKMM wasn't the responsibility of $\mathrm{Hj}$.Eulis.

Hj. Eulis's social care wasn't only limited to women's organization, but also extended to Islamic and youth organizations. Hajah Eulis is a peaceful place for many community and youth organizations in Ciamis Regency. She became a mother to many Islamic and youth organization. If anyone had any organizational problem, $\mathrm{Hj}$.Eulis was a person to talk to. For example, when Hizbu Tahrir Indonesia (HTI) was dissolved by the government, the managers in Ciamis Regency asked her advice for their next steps. Hj. Eulis showed her 
ljtihad: Jurnal Wacana Hukum Islam dan Kemanusiaan, Volume 18, No. 1, Juni 2018: 57-80

care and attention to HTI and advised the managers to channel their aspirations peacefully without anarchy.

Hj. Eulis cared for youth organizations in Ciamis Regency, e.g. Ciamis Nature Lovers Organization (Damapala), Darud Dakwah Jami'ah (DDJ), Muslim Student Association (HMI) of Ciamis, Indonesian Muslim Student Association (PMII), Student Representative Council (DPM), Student Executive Board (BEM), Hizbu Tahrir Indonesia (HTI), Islamic Economic Community (KSEI), and SUKA Community. She assisted youth organizations with varying ideologies and backgrounds with finance and ideas, e.g. providing pesantren's facilities such as building and equipment for organizational events for free. Some organizations were provided facilities and finances. Many youth organizations didn't hesitate to ask for financial aid for their activities. No matter the condition, Hj. Eulis always provided financial aid for youth organizations for their activities.

"Mrs. Dra. Hj. Eulis Fadillah Jauhar Nafisah, M.Pd.I. to us is a generous mother who is attentive to the growth and progress of organizations. She is also very close to students, always remembering our names after meeting us once. She's very patient and skillful in teaching younger generation, motivating to love science, excel in all fields. As the oldest daughter of Allahuyarham KH. Irfan Hielmy, it's clear that the nobleness of her father is passed down to Mother Eulis. Moreover, every time students hold event, she always provide moral, material, and facility aids". (Fajar, Ciamis activist, 17/10/2017).

For example, Nature Lover organization (DAMAPALA) is a youth organization in Ciamis. It made $\mathrm{Hj}$.Eulis their patron and teacher in running the organization. Their activities were always supported by $\mathrm{Hj}$. Eulis training cadres, performing programs, and holding events. In a competition for students and college students across Java, the sponsor suddenly withdrew, so the money reward promised by the sponsor couldn't be given. DAMAPALA committee frantically looked for fund. When they met male public figures, they were told that they didn't calculate their budget well. They couldn't find anything. When they met $\mathrm{Hj}$. Eulis, $\mathrm{Hj}$. Eulis immediately paid for the lack of fund (interview with an activist of Ciamis Damapala).

In social context, $\mathrm{Hj}$. Eulis joined many social activities. Every week she held peace building with discourse and lessons on women's rights, mandatory skills for women, leadership, togetherness and solidarity. $\mathrm{Hj}$. Eulis drove girls to care for others with activities which build communal bond, e.g. visiting the sick, women in labor, celebrations, pilgrimage 
Care ethics of women as institutionalization of equality and peace building at grassroots level...(Sumadi)

thanksgiving, and social service. "Her attention is unmistakable. She really supports students and youth's activities materially and non-materially. She also cares about the characters of her students because when we're wrong, she always reminds us with advices that reproach and educate us (Women activist of Ciamis, Nisa,26/10/17).

Hj. Eulis also financed picnic for pesantren teachers. It's a much anticipated moment and opportunity by the teachers of Darussalam pesantren, Ciamis. The pesantren teachers were very happy with the help for their picnic. Their fatigue and exhaustion after teaching disappeared when they heard that Hj.Eulis wound provide the money, food and accommodation for the picnic. With Hj.Eulis' help, pesantren teachers could relax and rejuvenate themselves by visiting tourist attractions all over Indonesia e.g. Yogyakarta, Jakarta, and Cirebon.

Hj.Eulis had programs to distribute social aids to the public, i.e. distributing sacrificial meat, infak, zakat, and alms. These activities developed empathy, care, and responsibility to others. Hj. Eulis' attention wasn't only local, but also mondial. She cared about the people of Palestine. She was also sad about the conflict between Palestine and Israel. She believed the countries should be able to live peacefully. Therefore, when KNRP (National Committee for the People of Palestina) of West Java held a religious music concert to raise fund for the education of the people of Palestine, $\mathrm{Hj}$. Eulis gave inspiring donation. Compared with the donations of male leaders, religious leaders, political parties, and Regent in Ciamis, Hj.Eulis gave the biggest donation.

\section{Mrs. Dasiah is a village head: maintaining care, answering doubt and uniting dif- ferences}

It wasn't easy for Dasiah to be a village head. With patriarchal culture, masculine religious interpretation, and strong sexual politics in the society, female leader causes polemic. However, Dasiah's long history of sensitivity and care to her community made people trust her to be their village head.

Dasiah was born and raised to be a servant to her community. She was a tough and selfless public servant. As a victim of domestic abuse who was abandoned by her husband, she survived alone to raise her children and serve her community. The abuse Mrs. Dasiah experienced didn't make her desperate and upset for a long time. After her husband left her, she tried to remarry. However, two months after their wedding, her second husband 
ljtihad: Jurnal Wacana Hukum Islam dan Kemanusiaan, Volume 18, No. 1, Juni 2018: 57-80

she was relying on passed away.

She tried to recover from that by joining social activities in her community. To Dasiah, sincere care for others is the key to survival. She believed sharing and caring were a way of life based on religious principles. Since she was a child, she was taught to be a public servant. Mrs. Dasiah started her participation in her community by being the chairwoman of Women Farmer Group (KWT). Dasiah enthusiastically empower her community, asking the women farmers around her to join productive agricultural activities, e.g. planting rice and various types of secondary crops. Slowly, the community was able to perform various agricultural activities to fulfill their needs.

Due to her participation in her community, Dasiah started to be well-known in Sindangangin Village. Whenever there was any training on agriculture and women's skills, the village and sub-district assigned Dasiah. The trainings she joined didn't only benefit her. She believed that the knowledge and skills she gained must be shared with the community. Therefore, after training, Dasiah held her own training in the community with fund and equipment she provided on her own without the aids of the village and sub-district. After holding the training, Mrs. Dasiah reported it to the village and sub-district. Every time, she gained new knowledge and skill, she immediately shared them with her community.

The participation and attention of Mrs. Dasiah, led her to be a cadre in Integrated Service Post (Posyandu). With her own money, she established Posyandu and Early Childhood Education Program called Sakura. It wasn't easy to establish and initiate a Posyandu. In 2000, there wasn't any program supplied by the government. Every week, Mrs. Dasiah made porridge for children and their mothers so that the women gained awareness to check their children's development in Posyandu. Thanks to her perseverance in making porridge for children and their mothers, women started to become drawn to Posyandu. Slowly but surely, the Posyandu she established became a gathering place for the community.

The care and significant role of Dasiah made Nahdlatul Ulama (NU) is Lakbok Subdistrict appointed her to be the chairwoman of Muslimat in Sindangangin Village. Recitations and silaturabim for women started with the establishment of Muslimat by Dasiah. Dasiah's skills and attention led to her appointment as a manager of Muslimat NU in the economic and cooperative section. For trainings, Ciamis Branch NU always sent Mrs. Dasiah. She 
learnt from various trainings, so she developed her leadership and community empowerment.

Due to the number of activities and organizations Dasiah led, she was considered a "mother" by the community for women, men, and children to take shelter. People knew that Dasiah was a selfless active figure in the community, so any problem they faced was informed to Dasiah. People who didn't know how to make Family Card (KK) and Identity Card (KTP) came to her house to ask her to take care of them at neighborhood, village, and sub-district levels. Many paid for her fuel, but some didn't. There were also many poor and sick people who didn't have any money.

From 2000 to 2008, the village didn't know about BPJS. There was Community Health Insurance (Jamkesmas) but the procedure to get it was complicated. People couldn't handle complicate bureaucracy. Moreover, the referral hospital and regency office are $50 \mathrm{~km}$ away. Dasiah helped the poor to get treatment. She worked hard by riding motorcycle to deal with complicate bureaucracy to make sure that the poor were treated. Dasiah said " $T$ believe that at that time a lot of people could do what I did, but few were willing to do it because finishing the process requires patience and hard work" (Interview, 31/10/17). She never thought about profit. Sometimes she even had to pay for the expenses first. The most important thing for Dasiah was she was able to help people around her. She did it sincerely and with a sense of humanity. Her children followed her footsteps. One of her children became a teacher of over a hundred children for free. Her children did what their parent did.

Care ethics are deeply rooted in her and her social activities, so that surprisingly people appointed her to be their village head. When Dasiah became a candidate for village head in 2013, no man was selected as a candidate of village head.

The MUI Chairman of Sindangangin Village, an influential ulama with mastery of religious literature said that initially theologians disagreed with female leadership. They were concerned about women's inability to lead. However, after seeing her achievements, journey and abilities, MUI approved Dasiah's leadership in her community. The ulama decided to accompany Dasiah. The theologians who doubted female leadership started to support her after she led Sindangangin for a time. The oppositions became the village head's number one supporters.

Since 2013, she became the only female village heads in Lakbok Sub-district and the 
ljtihad: Jurnal Wacana Hukum Islam dan Kemanusiaan, Volume 18, No. 1, Juni 2018: 57-80

surrounding areas. She governed the village as she lived, by being oriented toward social care. According to the village secretary (Sekdes) Sarkum, that was why many programs violated implementation guideline and technical guideline of the government. "Many programs were implemented based on compassion and bumanity, violating implementation guideline and technical guideline. Sometimes it was difficult to report the programs because they should be in accordance with the implementation guideline and technical guideline, because sometimes there were real necessities not included in the guidelines (Interview with Sarkum, Sindangangin Village Secretary, 31/10/17).”

Beside an administrative service office, a village is the center of conflict resolution in the community. There were at least 5 family conflicts which couldn't be resolved by the families and ulama, i.e. conflicts on inheritance. Mrs. Dasiah, the village head, mediated them to reach understanding and ended the conflicts. Mrs. Dasiah and village officials help mediation by inviting religious and legal experts to bring certainty to the conflicts. With care, religion and law, the disputing people were satisfied, so that none of the cases ended in court. The conflicts were solved with discussion at village level.

\section{Hj. Herman, based on mosque toa: caring and uniting to reject provocation}

In Ciamis Regency, this woman is known as Hj. Herman. Her real name is Hajah Hayatini. Because she is known with her husband's name, in Ciamis Regency and Banjar in West Java, she's known as Hajah Herman. She wasn't involved in politics and community organizations. Hajah Herman also didn't join Indonesian Islamic organizations, e.g. NU, Muhammadiyah, Persis, PUI, etc. From young age, she started a business career that continued after she built her own family and grew older.

Since her husband, Mr. Haji Herman passed away in 2006, she decided to focus on fertilizer, plant medicine, and plant seed business. With her perseverance, Hajah Herman became a successful businesswoman in Ciamis. The death of her husband didn't put her in prolonged mourning and stop her business. Before her husband died, Hajah Herman was also actively involved in the business with him. Therefore, she became an empowered woman who doubled as the head of her family after her husband passed away.

The profit of her fertilizer business wasn't used for fun or for her children. Three of her children were already independent. They didn't depend on their mother because they were 
taught to be empowered from a young age. Therefore, most of her income as a business was used for social causes. To Hajah Herman, setting aside her profit for social issues was an important part of the principle in her family. Helping the poor and community activities is inseparable from business activities. Caring and business were two sides of the same coin.

One of the forms of Hajah Herman's care was constructing places of worship and early childhood educations/kindergartens Her concern was passed down by her parents, who taught her to care for her community by constructing mosques and early childhood educations. To her family, mosque is a place for social and communal bonding. Mosque can build togetherness among community members. The mosques and the surrounding areas were used as a playground for children to make them religious and smart from young age. That's why the mosques built by Hajah Herman and her family were always equipped with early childhood educations, i.e. kindergartens.

Today, Hajah Herman and her family had constructed three mosques and early childhood education institutions, i.e. Saidiyah Mosque and Kindergarten in the center of Banjar; Mujahidin Mosque and Kindergarten in the center of Ciamis; Baitussalam Mosque and Kindergarten in Sukamanah, Banagara Village, Ciamis Regency. The costs of lands, buildings and equipment were borne entirely by Hajah Herman.

The mosques and early childhood educations were part of "amal sholeh and amal jariyah". Amal sholeh was an individual's good deed which benefits social life. Amal jariyah is good deed which benefit a lot of people for a long time, e.g. repairing road and drains, constructing places of worship and educational institutions, etc.. Amal jariyah is one of amal sholeb which has communal benefit.

The three mosques constructed by Hajah Herman were worth billions of rupiah. However, Hajah Herman and her family were happy to care for and help the community by constructing mosques and educational institutions.

Hajah Herman didn't only buy lands, construct mosques, and establish early childhood educations but also financed their operations, e.g. mosque Imam, mosque caretaker Marbot, early childhood education expenses, Islamic Holiday Celebrations (PHBI), and helping the poor. "Hajah Herman not only endowed mosques with its lands and facilities, but also finances the managers, Imams, and Islamic holiday events" (interview with Alipudin, Ciamis 
ljtihad: Jurnal Wacana Hukum Islam dan Kemanusiaan, Volume 18, No. 1, Juni 2018: 57-80

Mujahidin Mosque Family). Mosques were managed to be centers for social care and unifier of the people.

One of the three mosques constructed by Hajah Herman is located amidst diverse religious communities. The mosque in the center of Ciamis is flanked by Hok Tek Bio Temple and St.Johanes Catholic Church. The mosque and the area was bought by Hajah Herman from a Confucian Chinese residence. That's why the mosque in located amidst Christian, Catholic, Confucian, and Muslim communities. That's why the mosque has unique Toa on the roof to show harmony and respect for diversity although the majority of Ciamis Regency population is Muslims.

The mosque, called Mujahidin mosque, is expected to be a place for jihad which is harmonious, peaceful, and friendly among diverse communities. So, Hajah Herman believed that all mosque activities shouldn't deviate from the vision, although there were occasional differences between her and the managers of Board of Mosque Family (DKM) which sometimes violated the vision. For example, in an Islamic holiday celebration, they invited a provocative lecturer who talked about dividing religious groups. It gained their attention and produced an agreement that if they were to invite any lecturer, they should be free from divisive ideology. The agreement shows awareness that mosque Toa must be maintained to spreading peace.

Mujahidin Mosque which is attached to Hok Tek Bio Temple and across the street from St.Johanes Catholic Church was managed with understanding and awareness. Various religious activities were arranged by respecting other religious communities, i.e. respecting time of worship, respecting holiday celebration, and performing social activities. For example, during Confucian holiday, some Muslims received alms from the Confucians. Similarly, some Confucians received sacrificial meat. Social events in the church were also performed together. Some Muslims attended the birthday celebration for the pastor or father who led the church. If "muludan" took place at the same time as any religious event of the other communities, they agreed on taking turn. It started with muludan, the Confucian, Catholic and Christian holiday celebrations.

Islamic weddings usually took place in Mujahidin Mosque while the receptions in the hall of Hok Tek Bio Temple. The hall was constructed amidst polemic and controversies 
among the society and Islamic organizations in Ciamis, but to people of any faith around the temple, it was a symbol of togetherness. That's why the temple hall is located next to the mosque to show diversity around it. To Hajah Herman, Mosque Toa is the center of unifying compassion, not a place to spread hate and provocation. Toa, Dragon, and Cross are symbols in the center of Ciamis, to the people Ciamis are symbols of saling asih, saling asah, and saling asub (loving each other, taking care of each other, and maintaining each other).

\section{Eliminating exclusivism, strengthening emancipation, and bringing the public closer together}

After nearly three decades since the reformation with civil society empowerment, conflicts are usually solved without any casualty. In a society without conflict, i.e. peaceful and harmonious society, there are various community entities which maintain the peace.

Women with their capacities have played their roles to protect and maintain peaceful life. That's why at grassroots level there are many women who become agents of peaceful and harmonious life to create social order. Why are they able to build peace in the society? Women's increasingly strong development in various aspects of life corresponds with their confidence to be public leaders in their roles.

The logic of care ethics (social care ethics) of the women in this study, i.e. Hajah Eulis, Mrs. Dasiah, and Hajah Herman, was a major contribution by the women to maintain peace in the society. The care Ethics displayed by the women in their activities produced peace at family level to society level. Gilligen (Maharani, 2013) explains that in building human sociality, the perspectives of men and women have different basis. Men use the basis of equal rights ethical principle, while women use social care ethics. With care moral, women have greater maturity than men in deciding on an action. Perspective on right an justice potentially creates conflict.

This finding provided criticism and awareness what women aren't weak. It implied that it was a mistake to let men dominate formal peace building domain. In social cultural and political contexts, women still experience inequality. Emancipation requires various strategies. Social works and care performed by women like Hajah Eulis, Mrs. Dasiah, and Hajah Herman gave space to fight for three important things for women, i.e.: first, equality; 
ljtihad: Jurnal Wacana Hukum Islam dan Kemanusiaan, Volume 18, No. 1, Juni 2018: 57-80

second, emancipation; and third, institutionalization of peace building in community. Social work and social care are activities which can be performed by anyone regardless of gender. Therefore, slowly but surely the participation and efforts of women in the society among the general public gain social recognition. Public's attitude which used to be exclusivist, doubting women's leadership in public, was disproven by women like Mrs. Dasiah, Hajah Eulis, and Hajah Herman.

What women did at grassroots level with the paradigm of care became the priority. For care, they denied ideologies, community organizations, and anyone to gain affection. In the framework of Sachico Murata (1996), a world controlled by rough and aggressive masculinity has been tamed by motherly feminine attitudes which are caring and lovingly nurturing. This was different from the political construct of "mother" in the New Order of Indonesia which shackled and confined women. Mother in the present context maintained femininity to as social balance and relaxation to reassure life.

Hajah Eulis with leadership ability in education and social community organization gained social recognition from Muslim community and Muslim youths. This implied that she managed to institutionalize peace building in the community. She became a reference for men and women in behaving. Leadership model based on moderation became a peace building institutionalization movement which was followed by men and women. Mrs. Dasiah led Women Farmer Group, hamlet-level muslimat, and her village to answer people's doubt. For her social care and social works at grassroots level, she was able to unite diversity. People finally entered communal awareness in recognizing that gender isn't an issue in public policy management. Everyone has the same opportunity. Hajah Herman didn't formally lead anyone like Hajah Eulis and Mrs. Dasiah, but her power over social care made her a community leader without any formal position. She gained recognition for her economic achievements by constructing mosques as a facility for social care and headquarter for peace. Hajah Herman had great influence in the mosques and public and became reference for peaceful life. Her attention to educational institutions and social activities gained her social recognition as a empowered and unifying woman.

In this context, women were able to institutionalize equality and peace building with care ethics. In the history of Islamic civilization, Schimmel (1996) describes Siti Khadijah, 
who was called the "mother" of Muslims, who displays comforting, placating, and loving personality. The attitudes of Khadijah was reassuring Prophet Muhammad SAW when he was nervous and confused after receiving the first revelation. With her loving support, Muhammad received revelations and spread Islam. Similarly, Siti Aisyah, another wife of Nabi Muhammad, didn't only have strong political influence during conflict, but also a source of many hadiths as forms of transformations of the personality and teachings of Propet Muhammad SAW. The third is Fathimah, the youngest granddaughter of Rasulullah SAW, who married his cousin Ali, mother of Hasan and Husein, the first and second Shia Imams. Fathimah played the roles of a mediator and intermediary in dynamic life. In Shia, Fathimah has very high position with the title of "ummu abiha", mother of the father who becomes the source of inspiration and praises of Shia people. Major Sufi figures were also inspired by her mother.

\section{Implication and advocacy}

Social is shared space which doesn't discriminate gender. Women have more potential with the power of femininity to build peace. Therefore, maximizing femininity could be a emancipation and peace building strategy. As a strategy, women have received partial recognition from the start, which then slowly accumulate socially, i.e. people realizing that women have performed many activities that men do and even surpassed them.

Care ethics by maximizing femininity has been received in the society. Social care is an arena which doesn't discriminate or subordinate. It's an arena which units differences, including providing opportunity for competition and contestation to anyone. Therefore, this arena should become mainstream as an emancipation strategy. Social care strategy encourages women to have social sensitivity to perform contestation in building emancipation.

Gilligen (Maharani, 2013) states that the concept of social care ethics raises new awareness that differences are foundation for building strong social collectivity. Therefore, with social care ethics, women become moral agents. That's responsibility in a relation. Care ethics is an effort to eliminate domination, superiority, and inferiority. With care ethics, interpersonal relation in human social life between man and woman is performed with recognition of individual, seriousness in communication, avoidance of violence by recovering care. The 
ljtihad: Jurnal Wacana Hukum Islam dan Kemanusiaan, Volume 18, No. 1, Juni 2018: 57-80

implication on conflicts (Oktaviana, Santoso, Purwoko, 2014) is that it's safer to make women agents of peace because generally the disputing agents can accept women to negotiate to reach peace agreement.

Therefore, the advocacy which should be done is encouraging women to join social care. Social care should be the main concern to develop an arena for women to do their activities. Social care will develop peace because social care is an arena with an atmosphere which disregards gender, race, tribe, citizenship and religion. It's a unifying universal arena. So the dimensions of care ethics are emancipation and institutionalization of peace building.

\section{Conclusion}

Care ethics by maximizing femininity creates space for equality and peace. West Java is known for the highest number of cases of intolerance which are mostly committed by Muslims. This can be solved by peace building role of Muslim women at all levels. Muslim women at grassroots level of regencies and villages like Hajah Eulis, Ibu Dasiah, Hajah Herman, and other women not mentioned in this study showed various caring activities which received social recognition for their ability and peace building. In some cases, women were able to exceed men in action and performance.

Care is an area for social recognition for women, which doesn't cause resistance from the public. Therefore, it should become mainstream to institutionalize social equality to build harmonious and peaceful life. Advocacy for women empowerment in care is important to institutionalize emancipation or equality which builds peaceful community life.

\section{References}

Carolina, Rosita. Peran Perempuan Dalam Melestarikan Lingkungan, Jurnal Keluarga Sehat Sejahtera Vol. 11 (22) Des. 2013 ISSN : 1693 - 1157

Fakih, Mansour. Analisis Gender dan Transformasi Sosial. Yogyakarta: Pustaka Pelajar, 1997.

Gamble, Sarah, Feminisme dan Postfeminisme, Tim Jalasutra translation. Jogyakarta: Jalasutra, 2010

Haynie, Jeannette. The Women and Peace Hypothesis in the Age of Nancy Pelosi: Can Female Leaders Bring About World Peace? University of New Orleans Theses and Dissertations. 1399. http:// scholarworks.uno.edu/td/1399.2011

Hutabarat, Leonard F. Peningkatan female peacekeepers Indonesia dalam misi pemelibaraan 
Care ethics of women as institutionalization of equality and peace building at grassroots level...(Sumadi)

perdamaian PBB, Jurnal Pertahanan \& Bela Negara | Agustus 2017, Volume 7 Nomor 2 Irawaty, Diah. Politik Seksualitas dan Pengabaian Negara terhadap Kekerasan Seksual di Indonesia, Jurnal Perempuan No. 89, Mei 2016.

Ismiati. Ekesistensi Aktivis Perempuan Dalam Mewujudkan Perdmaian di Aceh, Jurnal Al-Bayan / Vol. 22 No. 33 Januari - Juni 2016

Kusmana. Menimbang Kodrat Perempuan antara Nilai Budaya dan Kategori Analisis, Refleksi, Volume 13, Nomor 6, April 2014, p.779-800

Maharani, Septiana Dwi Putri. Mengurai Akar Masalah Hubungan Antar Jender Dalam Konsep Etika Kepedulian Carol Gilligan: Sebuab Perspektif Filsafat Manusia, Prosiding The 5th International Conference on Indonesian Studies: Etnicity And Globalization, ICSSIS Universitas Indonesia, p.317-322, 2013.

Murata, Sachico. The Tao of Islam: Kitab Rujukan tentang Relasi Gender dalam Kosmologi dan Teologi Islam. Cetakan II, Terjemahan Rahman Astuti dan M.S. Nasrullah, Bandung: Mizan, 1996.

Nafisah, Eulis Fadlillah Jauhar. Konsep Pendidikan KH. Irfan Hielmy, Makalah dipresentasikan pada Studium Generale BEM KM IAID tanggal 17 Mei 2017.

Panggabean, Rizal, Ali-Fauzi, Ihsan (ed). Pekerja Binadamai dari Tanah Pasundan, Pusat Studi Agama dan Demokrasi Yayasan Wakaf Paramadina, 2017.

Press-Release Women Peace Conference II 22 April 2017, bttp://travel.tribunnews. com/2017/04/22/women-peace-conference-ii-karena-wanita-lab-dunia berubah-intip-event-soka-gakkai-di-sini?page=2, tanggal 22 September 2017.

Schimmel, Annemarie, Rahmani Astuti dan M.S. Nasrullah translation, Pengantar dalam Sachico Murata, The Tao of Islam: Kitab Rujukan tentang Relasi Gender dalam Kosmologi dan Teologi Islam, Cet.2 Bandung-Mizan, p. 15-19, 1996.

Sentiela Ocktaviana, Widjajanti M. Santoso, dan Dwi Purwoko. Peran-Peran Perempuan Di Wilayah Konflik: Antara Korban, Penyintas, Dan Agen Perdamaian, Jurnal Masyarakat \& Budaya, Volume 16 No. 3, 2014.

Sumadi. Gender Bias in Salafiyah and Modern Pesantren in Indonesia, International Journal of Social Sciences Research | Vol. 4, No. 1, 2016, p. 67-82.

Sumadi. The Development of Feminist Epistemology in Islamic Studies in Indonesian University, epistemé, vol. 12, no. 1, juni 2017, p. 231-259

Tobach, Ethel. Women and Peace, Peace and Conflict: Journal of Peace Psychology, Vol 14, p. 5-21, 2008.

Tong, Rosemarie Putnam, Feminist Thought: Pengantar Paling Komprehensif kepada Arus Utama Pemikiran Feminis. Cetakan V, Terj. Aquarini Priyatna Prabasmoro, Yogyakarta: Jalasutra, 2010. 
ljtihad: Jurnal Wacana Hukum Islam dan Kemanusiaan, Volume 18, No. 1, Juni 2018: 57-80

Widiati, Wahyu Pratiwi, Orientasi Moral Keadilan dan Orientasi Moral Kepedulian: Suatu Kecenderungan Perbedaan Antara Penalaran Laki-Laki dan Perempuan, Jurnal Cakrawala Pendidikan, XXII, No.1, p. 31-48, Februari 2003.

Wieringa, Saskia. Ibu Or The Beast: Gender Interests in Two Indonesian Women's Organizations, Feminist R eview No 41, Summer 1992, p.98-113

Wulandari, Primatia Romana, Women and Peace-building in Aceh Barat District, Indonesia: Women's Roles and Experiences and the Potential for a Gender Sensitive Approach Based on a Case Study of NGO Sunspirit, A Research Project Submitted to Van Hall Larenstein University of Applied Sciences In Partial Fulfilment of the Requirement for The Degree of Master of Development, Specialization Social Inclusion, Gender and Rural Livelihood, Wageningen, The Netherlands, 2009.

\section{Internet references:}

Balitbangdiklat Kemenag, 2017.Indeks Kerukunan Umat Beragama di Indonesia, www. balitbangdiklat.kemenag.go.id/posting/read/537-SUDUT-ISTANA-IndeksKerukunan-Beragama-di-Indonesia-7536, 5/10/17

Beritasatu. 2017. www.beritasatu.com/megapolitan/447965-radikalisme-tidak-punya-tempatdi-indonesia, 5 oktober 2017.

Kemenppa, 2017. kemenpppa.go.id/index.php/page/read/30/342/kesenjangan-gendermasih-terjadi-di-jawa-barat, 5/10/17

Metrones, 2017. www.metrones.com, Hukum _ Survei Wahid Foundation, 11 Juta Muslim Indonesia, 4 Oktober 2017.

Pikiran Rakyat.2017, www.pikiran-rakyat.com/nasional/2017/01/10/jabar-masih-jadiprovinsi-paling-intoleran-390238, 5 Oktober 217

Wahid-foundation, 2017, www.antaranews.com/berita/577774/intoleransi-terbesar-di-jawabarat, 4 oktober 2017. 